\title{
Young Aspiring Globals (YAGs): \\ Early-Stage Strategies of Knowledge-Focused International Entrepreneurs
}

Paul Brockman, Douglas Dow, Hoang Long Phan; Hussain Gulzar Rammal*, Ralf Zurbruegg

*Corresponding Author

Accepted for publication in Journal of Knowledge Management on 4 August 2021 https://doi.org/10.1108/JKM-05-2021-0375

\begin{abstract}
Purpose: This study explores the intention-action relationship of small and mediumsized (SMEs) firms with knowledge capital that declare their intention to internationalize from their inception.

Design/methodology/approach: We apply the theory of planned behavior and handcollect a database of Chinese born globals, purely domestic firms, and traditionalexporting firms. Our hypothesis is that Chinese born globals (or young aspiring globals YAGs) will strive to acquire domestic and international patents at an early stage to institutionally protect their knowledge-capital via intellectual property rights as they enter the competitive global marketplace.
\end{abstract}

Findings: The results confirm that knowledge-focused young aspiring globals apply for patents at an earlier stage than purely domestic and traditional-exporting firms. However, in the long run, these firms are neither demonstrating increased knowledge capital by being more innovative nor producing more valuable innovations than their counterparts.

Originality: This study tests the intention-action relationship in the context of SMEs internationalization. It contributes to the internationalization literature by identifying the internationalization pattern of born globals (YAGs) from emerging markets and providing an explanation for what happens to these firms as they mature.

Keywords: Entrepreneurship; Internationalization; Knowledge capital; Patents; Theory of Planned Behavior; Born Globals 


\section{INTRODUCTION}

The research on international entrepreneurship (IE) has contributed significantly to our understanding of the internationalization of the firm (Knight and Liesch 2016), and highlighted the role of national institutions in promoting entrepreneurial activities (Naudé and Rossouw 2010). There is also a growing literature focused on firms that strive for rapid internationalization, commonly referred to as born global (BG) firms. Rennie (1993) coined the term BGs to refer to firms that do not follow the step-wise internationalization model by seeking global markets from their establishment. Knight and Cavusgil (2004) define BGs as business organizations that seek international opportunities from or near their founding. A related term used in the literature is international new ventures (INVs), which refers to business organizations that, from their inception, seek to derive competitive advantage from the use of resources from and sales in multiple countries (Oviatt and McDougall 2005). Although there are similarities between these two concepts, there are differences in their form and how they are organized (see, for example, Cavusgil and Knight 2015). Hence, Coviello (2015) suggests that using the terms INV and BG synonymously is inaccurate.

There have been recent attempts to explain how and why BGs internationalize more rapidly than non-BG firms (Choquette, Rask, Sala and Schröder 2017, Muralidharan and Pathak 2017) The drivers include macro-level issues such as the institutional environment and home country networks, as well as the intention and international experience of the firms' entrepreneurs (Falahat, Knight and Alon 2018, Jiang, Kotabe, Zhang, Hao, Paul and Wang 2020).

While much is known about the initial internationalization of BGs in terms of their form and geographic focus, two issues remain under-researched. The first issue relates to what happens to these firms over time? The second issue relates to whether 
the experience of BGs from emerging economies is similar or distinct from BGs from developed economies. In their 2015 reflection article, Cavusgil and Knight (2015, p.10) identify several 'lines of inquiry [that] are especially desirable and promising.' They argue that (p. 12) 'a key question that has been very little addressed is what happens to born global firms when they grow up? (italics from the original) How do they evolve and what patterns of change are observed.' In addition, Cavusgil and Knight (2015) identify another important area of future research as follows (p. 12): 'Research is also needed on any distinctions between born global firms from the advanced economies and those from emerging markets'. As highlighted by Zander, McDougall-Covin and Rose (2015), much of the IE literature focuses on firms that originate and operate in developed economies (Schwens, Zapkau, Bierwerth, Isidor, Knight and Kabst 2018). In contrast, fewer studies examine the establishment and development of IEs in emerging economies (Yamakawa, Khavul, Peng and Deeds 2013), even though emerging markets are playing an increasingly important role in the global economy.

These two issues motivate us to fill this void by hand-collecting data to examine a sample of small and medium-sized (SME) born-global firms in an emerging market (namely, China) that express their intention to become IEs from their inception and examine their intention-action behavior over time. We refer to these firms as young aspiring globals (YAGs). To elaborate further, the intentionbehavior interplay related to internationalization is key to our understanding of entrepreneurs' ventures into international markets. It is the central tenet of the theory of planned behavior (TPB), which we use to theoretically motivate our study. Our hand-collected database enables us to identify Chinese SMEs' internationalization 
intentions at the time of their inception to help answer what impact this has on the internationalization process.

Moreover, the data we collect allow us to analyze these SMEs for up to 10 years after their establishment, thereby letting us explore what happens to these firms as they grow up. Specifically, we focus on the innovation outcomes of these firms over time. The relationship between knowledge capital and innovation and firms' economic performance has been established in the literature (Cabrilo and Dahms 2018, Lee, Lee and Garrett 2019). However, Kafouros, Buckley, Sharp and Wang (2008) argue that a sufficient degree of internationalization is required for firms to successfully capture the benefits of their innovation. Using patent applications as a measure of firms' knowledge capital and innovation performance, Ren, Eisingerich and Tsai (2015) also find a positive relationship between the degree of internationalization and innovation performance of SMEs.

Given that we expect entrepreneurial firms to be knowledge-focused innovative enterprises (Buccieri, Javalgi and Cavusgil 2020, Knight and Cavusgil 2004, Toms, Wilson and Wright 2020, Zia 2020), these firms should be following a planned path to venturing internationally and seeking to exploit international opportunities from their innovations if they have the intention to internationalize. To achieve this, these firms will need to establish and defend intellectual property (IP) rights. Therefore, we expect they will accomplish this strategic activity primarily by registering patents for their knowledge capital displayed through innovations in domestic and foreign markets (Liu, Tan, Li, Cao and Yu 2021). By focusing on Chinese firms that produce patents, we stay true to the definition of IE firms being knowledge-focused innovators that require IP protection, and avoid including those firms that merely export low-level manufactured goods. 
Since BG firms are also expected to have the intention to internationalize from the very inception (Jones, Coviello and Tang 2011), they should also have an additional motivation to patent early-on in preparation for their planned internationalization. By applying the theory of planned behavior (TPB) to explore the intention-action relationship to internationalization, we expect that our sample of BG firms, which we check as having an ex-ante intention to internationalize, will file for patents at an earlier stage in their development relative to non-BG firms, including purely domestic (PD) firms and traditional exporting (TE) firms that did not initially have the intention to internationalize from inception. Our speed-of-patenting hypothesis also suggests that unusually early patent filings can act as credible signals of an emerging BG firm.

In addition to examining the initial speed of patenting, we also examine the ongoing patent production rate and the quality of patent ownership (using citations) between the sample of emerging market BG firms and our control groups of PD and TE firms. A higher frequency or quality of early-stage patenting (i.e., our speed-ofpatenting hypothesis) might simply reflect a greater overall capacity for innovation among BG firms. If BG firms produce more patents (per year) throughout their lifecycles, for example, then it would be challenging to identify early-stage patent production as a deliberate internationalization strategy. Unlike previous studies, our hand-collected database allows us to test hypotheses that distinguish early-stage from ongoing patenting activities because we identify potential BG firms on an ex-ante basis. Specifically, we manually check initial annual reports and other publicly available records for direct evidence that an SME intends to internationalize from its original creation. Such evidence often takes the form of articulated export plans or the establishment of a physical presence abroad when present. If there is any ambiguity in 
the printed evidence, we directly contact this BG firm to verify its intention to internationalize from inception. The key point is that we use a firm's stated intentions in our classification. We then track the early-stage patenting strategy that these firms use to achieve the status of IE within a relatively short period of time - given the constraints of originating in an emerging economy, including the burden of regulations, poor business infrastructure, and insufficient property rights protection. The study finds that the young aspiring globals (YAGs) as BG firms file for patents at an earlier stage of their development than non-BG firms. The speed of internationalization after receiving patents is also observed to be faster for these BGs. However, we find that in the long-run, the YAGs are neither more innovative nor produce more reliable innovation.

\section{INTERNATIONAL ENTREPRENEURSHIP}

The literature on firms' internationalization draws inspiration from the Uppsala model proposed by Johanson and Vahlne (1977). They suggest that firms internationalize incrementally by entering markets in close geographic proximity and by having low psychic distance levels from the home market. However, the IE field has highlighted firms that tend to internationalize from their inception, or soon thereafter, are not bound by geographic or psychic distance, and tend to continue expanding rapidly into new markets over time (Onetti, Zucchella, Jones and McDougall-Covin 2012).

The size, features, classification, and speed of internationalization of these early internationalizing firms have been the subject of investigation in many IErelated studies (see, for example, Coviello, Kano and Liesch 2017, Liesch, Welch and Buckley 2011). In the related literature, early internationalizing firms are referred to as born globals (BGs), innate exporters, infant international or INVs (Cavusgil and 
Knight 2009, Cavusgil and Knight 2015, Knight and Cavusgil 2004, McKinsey \& Company 1993, Oviatt and McDougall 1994, Zahra 2005). The distinguishing feature of these firms is their intention to internationalize their activities from the beginning of their founding and the speed at which they internationalize. That is, compared to firms that gradually internationalize, BGs seek international market opportunities from their inception.

The majority of the empirical studies on IE firms rely on surveys that do not capture how BGs progress over time. Although this can lead to an analysis of a large cross-section of firms, there are also drawbacks to not observing the time-variant features of these companies. As many of these studies capture the firms' activities a few years after their establishment, it is difficult to ascertain whether the intent to internationalize existed at the time of foundation or was a reaction to opportunities that emerged later (Coviello 2015).

Another issue that is raised in the literature relates to the criteria that define BGs. Although there is no set definition, early internationalizers are generally considered to include firms that internationalize soon after inception, and studies in IE have analyzed these new ventures anywhere between six years to 20 years from inception (Coviello and Jones 2004). These criteria are arbitrary (Knight and Liesch 2016) and do not necessarily take into consideration the nuances of the markets these firms operate under, highlighting the lack of consistency and the infancy of the IE field of research (Hewerdine and Welch 2013, Zander et al. 2015). Hennart (2014) attempts to explain the reasons for the rapid internationalization of the BGs by highlighting four distinctive characteristics of such firms: they sell products and services that are sought by customers internationally; they sell products and services that do not need to be adapted; they use low-cost delivery methods, and they are 
based in a country that has a small domestic market for the product or service being offered by the firms. In contrast, Baum, Schwens and Kabst (2015) provide a resource-based explanation and characteristics of the top management team for these firms' rapid internationalization. Using two surveys of Australian exporters, Dow (2017) tests the factors highlighted by Hennart (2014) and finds support for some of the elements and support for the resource-based view explanations as drivers for rapid internationalization views them to be complementary.

To further enhance our understanding of IE as a truly international phenomenon, it is necessary to investigate firms' operations and experiences from emerging economies (Zander et al. 2015) and multi-country comparisons (Terjesen, Hessels and Li 2016). In their review of the studies on IE, Coviello and Jones (2004) found that while more non-US studies have started to emerge, these remain primarily focused on developed economies in North America, Europe, and Australia-New Zealand. This is surprising given the growing number of entrepreneurs from emerging economies expanding internationally.

The transitioning economies of Central and East Europe, Central Asia, and China provide further opportunities to explore entrepreneurs' strategies as these countries move from centrally-planned to market-economies (Lamotte 2015). Naudé and Rossouw (2010) find that countries with a less conducive environment, a heavy burden of regulations, insufficient property rights protection, corruption, and poor business infrastructure are often associated with fewer start-ups and slow growth. These challenges, along with state-ownership of firms in emerging economies, have been the catalyst for informal entrepreneurship, where business ventures commence without registering with government agencies. Bu and Cuervo-Cazurra (2020) find that informal entrepreneurship leads to reduced innovation in emerging economies. 
For Chinese businesses, the country's membership of the World Trade Organization (WTO) on 11 December 2001 has provided firms opportunities to expand into new, international markets that were previously unavailable. Studies conducted on Chinese firms' performance, post-WTO membership, show a positive trend with rapid growth in international sales (Jiang and Kattuman 2012, Sachs and Woo 2003). The driver for this change has been the regulatory and institutional reforms that China has had to undertake as part of the WTO negotiations. The resulting reduction in bureaucratic processes and improved business environment has encouraged the internationalization of Chinese firms (Lin, Mercier-Suissa and Salloum 2016, Wei, Clegg and Ma 2015, Zhang, Ma, Wang, Li and Huo 2016). However, some studies also suggest that the Chinese entrepreneur's ideological imprinting can influence their decision to go international. In particular, entrepreneurs with communist ideological imprint tend to have a negative attitude towards internationalization (Marquis and Qiao 2020).

Data from the United National Conference on Trade and Development (UNCTAD), however, suggest that despite these opportunities, outward investment from China grew rapidly only after 2006 (UNCTAD 2018). This lag between China's membership of the WTO and its firms' internationalization is due to the amount of time it has taken for the reforms to take place, with government agencies still undergoing deregulation (Salidjanova 2011). In other words, joining the WTO in 2001 did not necessarily lead to immediate benefits, but rather it took several years to permeate through to changes in the entrepreneurial mindset and firm behavior (Marquis and Qiao 2020).

The above regulatory and knowledge impediments to trade and cross-border investment highlight the need to take care in using existing criteria of early 
internationalizing IE firms that are built around firms from developed economies, as compared to emerging and transition economies, and the need for studies that capture the intent to internationalize from the time of founding and the longer-term performance of these firms. This will also later help us define what born-globals are for our sample of emerging market firms.

\section{KNOWLEDGE CAPITAL, INNOVATION, AND INTELLECTUAL PROPERTY}

A part of the literature on knowledge management looks at the capabilities of IE firms to innovate and enter new markets. Knight and Cavusgil (2004) identify two major sources of innovation: (i) internal research and development (R\&D), which is related to the knowledge held by the individuals in an organization, and (ii) imitation of the knowledge innovation of other firms. This knowledge in small firms is endogenous and tends to be tacitly held by the CEO/founders, who identify opportunities to exploit their knowledge and produce output (Acs, Braunerhjelm, Audretsch and Carlsson 2009, Nonaka and Takeuchi 1995).

The association between knowledge, research and development (R\&D), and innovation has been explored from the perspective of firm size, board independence, and ownership, as well as internationalization of the activity (Carayannis, Ferreira and Fernandes 2021, Nieto and Rodriguez 2011, Rodriguez and Nieto 2016). However, strong intellectual property (IP) rights protection may also deter entrepreneurial activities, especially those related to imitation innovation. Pathak, Xavier-Oliveira and Laplume (2013) study 20 emerging economies and find that countries with strong intellectual property rights protection and high level of inward foreign direct investment decrease the likelihood of individuals' entry into technology 
entrepreneurship. The entrepreneurship literature also suggests that while many resource-intensive firms may have their base in developed countries, small innovative companies from emerging economies are moving away from imitating innovation to creating new knowledge (Mahmood and Singh 2003, Ramadani, Abazi-Alili, Dana, Rexhepi and Ibraimi 2017, Tekin, Ramadani and Dana 2021, Zaim, Ramadani, Dinibutun, Gërguri-Rashiti and Said 2021). This brings new challenges in protecting the firm's IP rights.

As a means to protect IP, patents are a straight-forward means to safeguard a firm's innovation and knowledge (Griliches 1984). They are also a useful means of measuring a firm's innovative performance (Szirmai, Naudé and Goedhuys 2011). Oviatt and McDougall $(1994 ; 2005)$ identify patents as one of the key elements for protection that allows BGs to make their success sustainable over time. Small- and medium-sized enterprises (SMEs) have a stronger reliance on monetary patents and use them more actively than larger firms (De Rassenfosse 2012). SMEs benefit from patenting in commercializing product innovations, which contributes to higher profit margins (Andries and Faems 2013). Holgersson (2013) found that even when the protective functions of patents are of secondary concern, SMEs use them to attract customers and venture capital. Symeonidou, Bruneel and Autio (2017) investigate the effects of IP-based, product-based, and hybrid commercialization strategies on internationalization propensity in technology-based new ventures. They find that new ventures using IP-based commercialization strategies have higher international intensity after they enter foreign markets compared to product-based or hybrid strategies (Symeonidou et al. 2017). As such, the importance of benefitting from a resulting knowledge innovation is directly related to the innovator's ability to establish IP, both domestically and abroad (Ivus 2015). 
Jaffe and Trajtenberg (2002) demonstrate the usefulness of patents and citation data to study the process of technological change and innovation as it includes information such as the inventor's identity, location, the technological field of the innovation, and citation references to previous patents. As patents are effectively an output measure of knowledge and innovation, we add to the literature by examining IE firms' behavior from a different perspective relative to the existing literature, capturing how they prepare for their internationalization by protecting, at an early stage, their innovations.

\section{THEORY OF PLANNED BEHAVIOR AND HYPOTHESES DEVELOPMENT}

Entrepreneurs' motivation to seek international market access is acknowledged as a critical factor in the internationalization of entrepreneurial firms (Dimitratos, Buck, Fletcher and Li 2016, Dimitratos, Voudouris, Plakoyiannaki and Nakos 2012). We apply the theory of planned behavior (TPB) to explain the intention-behavior relationship of our sample of emerging-market BG firms' internationalization. The TPB proposes that an individual's intention (or willingness to undertake a given behavior) determines whether they would take action and perform a task (Lortie and Castogiovanni 2015). A growing number of studies use TPB to study the link between entrepreneurial attitudes towards risk and entrepreneurial behavior (Ciravegna, Kuivalainen, Kundu and Lopez 2018). Therefore, the theory provides the opportunity to observe the intentions and the subsequent action taken by an individual.

Ajzen (1985) identifies three attitudinal antecedents of human behavior: behavioral beliefs, normative beliefs, and control beliefs. Behavioral beliefs refer to an individual's attitude about a particular behavior's potential outcomes and the outcomes' perceived values (Ajzen 1985). Behavioral beliefs influence attitudes 
toward the behavior (Ajzen 1991). Normative beliefs reflect perceived social norms regarding expectations towards the behavior (Krueger and Carsrud 1993). Normative beliefs produce subjective norms or perceived social pressures (Ajzen, 1985). Control beliefs are the actor's beliefs towards the feasibility of performing the behavior (perceived behavioral control) and his or her controllability over that behavior (Krueger \& Carsrud, 1993). Control beliefs affect perceived behavioral control (Ajzen 2002). The combination of attitude toward the behavior, subjective norm, and perceived behavioral control results in behavioral intention. To predict behavior, in addition to intention, actual control needs to be taken into account.

TPB is widely used to predict individuals' behavioral intentions and explain the entrepreneurial process (Munir, Jiangfei and Ramzan 2019). The key relationships studied is the link between values, underlying attitudes, and how they drive intentions and, subsequently, behaviors (Ruzzier, Douglas, Ruzzier and Hojnik 2020). Some recent studies have attempted to apply the TPB to explain entrepreneurial intentions and actions (Kautonen, Gelderen and Fink 2015, Obschonka, Silbereisen, Canter and Goethner 2015). However, most studies in the field tend to focus on the entrepreneur's intention only without considering the subsequent action. For example, Elson and Weidinger (2019) explore the level of regional internationalization in a country and entrepreneurial intent. Using the example of China, they find that regions with a high degree of internationalization tend to have lower entrepreneurial intent, while regions with a lower degree of internationalization tend to have a higher entrepreneurial intent (Elson and Weidinger 2019). Gieure, Benavides-Espinosa and Roig-Dobón (2020) highlight that TPB's intention-action aspect has not been studied, but their efforts also focus on understanding the genuine intention of university students towards entrepreneurship. Therefore, the application of the theory in this 
study is justified as our data not only identifies the intention of the firms to internationalize but also matches it against the action. The intention-action aspect also addresses the issue raised by Hennart (2014) of BGs being accidental internationalists. If the firms express the intent to internationalize at the time of inception and do so soon after commencing operations, then their internationalization would be a planned move.

The key consideration for early internationalizing firms is their intention to engage in international business activities from their inception. Therefore, these BG firms that we describe as young aspiring globals (YAGs), are expected to be aggressive in their international entry strategy as they seek to enter multiple foreign markets to exploit their innovations (McDougall 1989). The early and active pursuit of patent technology is an important component of such an internationalization strategy (McDougall 1989) since it demonstrates the SMEs' commitment to internationalize from their inception, thereby protecting their intellectual property from global competitors (Hsu and Ziedonis 2013). We, therefore, posit that internationalizing SMEs will display a very rapid speed of patent registration. More formally, this hypothesis is stated as follows:

H1: BG firms will demonstrate their commitment to internationalize from inception by filing for patent protection in the home and foreign markets at an earlier stage in their development relative to purely domestic (PD) firms or traditional exporting (TE) firms.

We should also find that the time it takes a BG firm to internationalize, relative to when it starts to apply for patent protection will be quicker. The literature on internationalization speed states that early adopters of internationalization will attempt to enter markets as quickly as possible (Acedo and Jones 2007). In the case of Chinese firms, Zhou and $\mathrm{Wu}$ (2014) find that firms that internationalize early tend to have positive sales growth performance, so there is a strong motivation to 
internationalize within a relatively short time horizon. From our perspective, BGs whose intentions from the outset are to internationalize will plan to internationalize as soon as their patents are filed. This contrasts to TE firms who may well file patents abroad but are not necessarily directly related to a staged internationalization plan. This establishes our second, testable hypothesis:

H2: The time between patent filings and internationalization will be shorter for $B G$ firms relative to traditional exporting (TE) firms.

One alternative explanation for BGs' early patent applications is that they are naturally more knowledge-focused and innovative than other firms. The knowledge nature of BG firms could imply the introduction of more products and services that require the protection of their innovation's intellectual property (IP) rights through patent registration (Siegel and Renko 2012). Therefore, the faster speed-of-patenting for BG firms may be an artifact of them being more knowledge-intensive and innovative, in general, compared to TE and PD firms, rather than it being related to their desire to internationalize, per se. To examine this alternative explanation, we test the hypothesis that:

H3: The average number of patents for knowledge-based innovation filed by $B G$ firms per year will be higher than that of traditional exporting (TE) firms and purely domestic (PD) firms.

Patents also represent a positive signal to the market and indicate knowledge capital and innovation quality (van Praag and Versloot 2007). One measure of the quality of a patent is the number of citations that it receives. Since BGs may be more reliant on the quality of their innovativeness than their TE and PD counterparts, we test whether BGs hold higher-quality patents (on average) than TE and PD firms. If BGs hold higher-quality patents, then their motivation for patenting earlier than nonBG firms might be to protect these high-value innovations instead of being a rapid 
internationalization strategy. We test this alternative explanation (i.e., high-value IP protection versus rapid internationalization strategy) as follows:

H4: The average number of citations for foreign and domestic patents will be higher for $B G$ firms than for traditional exporting (TE) firms and purely domestic (PD) firms.

\section{RESEARCH METHOD}

Chinese firms have rapidly built a reputation as strong innovators (Lin and Si 2019, Quan, Xiao, Ji and Zhang 2021), and are the second-largest spender on research in the world (Woetzel, Chen, Manyika, Roth, Seong and Lee 2015). Therefore, the need to protect their knowledge capital or IP is very strong. Stoianoff (2012) points out that China's membership of the WTO and commitments to agreements such as the TradeRelated Aspects of Intellectual Property Rights (TRIPS) has seen a stronger engagement from Chinese firms in the use of patents and other IP protection instruments, particularly as the need grows for protecting their innovations. China held the second position as the source for patent applications via the World Intellectual Property Organization (WIPO) in 2017, which according to the Francis Gurry, Director General of WIPO, indicates that Chinese innovators are increasingly looking outward to spread their knowledge and ideas into new markets (WIPO 2018). Li (2012) credits this surge in patents to the institutional changes at the provincial level in China, resulting in a larger fraction of applications being granted patent rights. This has led to an increased propensity for firms, universities, research institutes, and individuals to register their knowledge-led innovation. $\mathrm{Wu}$, Wang, Hong, Piperopoulos and Zhuo (2016), in their panel-data analysis of Chinese manufacturing firms, find that the institutional development enhances innovation performance, especially for firms that have a strong knowledge absorptive capacity 
and diversify into many countries. Given that IE firms are expected to be innovative, this motivates us to investigate Chinese firms' patent activities.

As discussed earlier, although China's WTO membership commenced in December 2011, it was not until 2016 that the increase in outward FDI was noticeable. Hence, in defining a BG within the Chinese context, we account for the fact that firms established before 2006 had greater impediments to conduct international trade than those established after this date (see Salidjanova 2011). Therefore, we use a two-tier classification for BG firms concerning when they first internationalize using either non-equity (exporting, licensing, franchising) or equity (joint venture, wholly-owned subsidiary) based modes of entry. If the firm is founded prior to 2006, we allow a 10 -year window for the firm to internationalize to compensate for the lag in the implementation of the WTO rules; if the firm is founded during or after 2006, we allow for a six-year window. We apply the six-year criteria as it is a common threshold used in the entrepreneurship literature to define a new international venture (Coviello 2015). We believe this schema is appropriate as it provides for the earlier firms to internationalize at a slower pace, recognizing the changing institutional environment in China before and after joining the WTO. As highlighted in previous IE research (Knight and Liesch 2016, Oviatt and McDougall 2005), the institutional environment is a major driver of a firm's internationalization. For this study, the firm's inception date is when it is first registered and/or incorporated as a company.

In particular, we invest effort into ensuring that the young aspiring globals (YAGs), the BG firms or in our sample, show the intention to internationalize from their inception or very early in their development. This is important because, without the intention to internationalize early on, the need to protect and patent innovations 
internationally diminishes. It is, therefore, vital for our study that we ascertain the firm's intention to internationalize.

To determine the intention to internationalize from the outset, we begin our search using the Thomson Reuters database to identify all firms within its dataset between 2002 and 2014 that we classify as being SMEs. Although there are various definitions of SMEs, we use the European Commission's (2020) definition that considers firms with less than 250 employees, sales revenue below 50 million Euro (55m USD or 350m RMB), or total assets of 43 million Euro (47m USD or 300m RMB). The European Commission's definition for SMEs is widely used in the literature, including for studies on early internationalizing firms in China (Ciravegna, Majano and Zhan 2014).

By filtering out all firms in the Thomson Reuters database that do not match the above criteria we are left with 318 firms. We then check which of these firms have internationalized by the end of our sample period, bringing the number down to 251 . This is further reduced when we require that the firm shows evidence of an intention to internationalize from its inception. We manually check the initial annual reports and other publicly available records for each of the firms to determine if they stated an intention from the outset to internationalize - whether in the form of export plans or having a physical presence abroad. If there is any ambiguity, we then directly contact the firm for further information pertaining to their initial internationalization plans. This leads to a final sample size of 43 BG firms based on our filters of being an SME, having the intention to internationalize, and then doing so within a relatively short time frame.

\section{ANALYSIS AND RESULTS}




\section{Univariate Results}

To test our hypotheses, we compare our sample of Chinese BGs (YAGs) with two control groups: a group of purely domestic (PD) Chinese firms and a group of traditional exporting (TE) Chinese firms. The first control group contains 99 SMEs matched to our BG group by size but never have had a presence abroad. These firms represent a purely domestic (PD) control group of firms. Our second control group contains 29 SMEs that do export, but not as early as our BG group, and although they do internationalize, there is no evidence of having an internationalization plan upon founding. We label this group as traditional exporters (TEs) to reflect their traditional route to internationalization. Our sample of firms is dispersed across several industries, with over half of the firms being in the industrial goods and services $(29.8 \%)$ and technology $(21.1 \%)$ sectors. ${ }^{1}$

We collect patent and citation data for all three groups from several sources. We start by conducting English and Chinese language Google patent searches. We record each patent's date, along with the patent office that the patent is filed at, plus the number of citations that each patent attracts. We then verify each patent using the World Intellectual Property Organization (WIPO) (World patent office), the United States Patent and Trademark Office (USPTO) (for US patents), State Intellectual Property Office (SIPO) (China) and European Patent Office (EPO) (Europe) databases. In total, 3,593 patents are identified for the 171 firms in our study. As expected, the bulk of the patents are Chinese $(3,186)$, with the remaining being foreign (407), attracting a total of 5,438 citations.

\footnotetext{
${ }^{1}$ BG firms (YAGs) by industry are: 9 in Basic Materials, 17 in Industrials, 8 in Consumer Goods, 3 in Health Care, 2 in Consumer Services, 1 in Financials, and 3 in Technology.
} 
Table 1 provides summary statistics of the patent and citation data that are collected for the sample of firms in our study. Two-tail $t$-tests for the differences in means of the two control groups (PD and TE) with respect to the $\mathrm{BG}$ group are conducted, and their significance asterisked (with mean differences in parentheses). The results show that BG firms have, on average, significantly more patents (at the $0.1 \%$ level $)$ filed on an annual basis than PD firms ( 0.24 more for foreign patents, and 0.40 more for Chinese patents), but significantly less than the TE firms.

Insert Table 1 here.

Regarding citations, there is no significant difference between the three groups (i.e., BG, PDs, and TEs) in terms of the average number of citations per foreign patent. However, there are significant differences between the three groups for citations per Chinese patent. Similar to the pattern observed for patent numbers, BGs have significantly more citations for their Chinese patents relative to PD firms $(0.85$ compared to 0.55$)$, but fewer citations compared to TEs, which average 1.57 Chinese citations per patent. Before controlling for other factors, these initial results suggest that traditional exporters are patenting more often than BGs and are filing more valuable patents (based on citations) than BGs.

When we focus on the speed in which firms file their patents, a different picture begins to emerge. Partly addressing the first hypothesis, we notice that the average number of years a BG takes to file its first patent (6.3 years) is approximately $45 \%$ shorter than its nearest rival TE firm (at 9.2 years). The same approximate time difference is also present for Chinese patents. When we compare the amount of time it takes for BGs to patent relative to when they start internationalizing, it is again significantly shorter. Specifically, BGs take 0.95 years to internationalize after filing 
a foreign patent, while TEs take 5.5 years; and BGs take 1.35 years to internationalize after filing a Chinese patent, while TEs take 4.05 years. Overall, these results provide supportive evidence in favor of our first hypothesis that BGs are more aggressive in patenting from their inception. Finally, we observe that TE patents are significantly older (at the $0.1 \%$ level) than BG patents (i.e., 1.63 years compared to 1.30 years).

\section{Multivariate Results}

The previous univariate results are supportive of the first hypothesis showing that BGs engage in speedy patent applications. In this section, we employ more powerful tests by using control variables in a multivariate regression framework to examine all four hypotheses. The tests utilize the following regression framework:

$$
\text { Filing behavior }_{i}=\alpha+\beta_{0} P D \text { dummy }_{i}+\beta_{1} T E \text { dummy }_{i}+\gamma^{\prime} X_{i}+\varepsilon_{i t}
$$

where Filing behavior represents one of the dependent variables that captures the filing behavior of firm $i$ that we use in our subsequent models. The main variables of interest are the two dummy variables. The $T E$ dummy takes the value of one if the firm is a traditional exporting company, and zero otherwise. The $P D$ dummy takes the value of one if the firm is a purely domestic company, and zero otherwise. The coefficients on these two dummy variables represent TE and PD firms' marginal effects, respectively, relative to BG firms. The vector $X$ represents a set of control variables selected based on the literature that examines firms' patenting behavior. These control variables consist of company financial and corporate governance characteristics. In examining US biotechnology firms' patenting speed, Al-Laham, Amburgey and Baden-Fuller (2010) account for firm-specific factors that can explain how quick firms are to patent their knowledge. Likewise, Reitzig and Puranam (2009) highlight the need to control for factors that influence the desire to seek rapid patent 
protection while, more generally, Andries and Faems (2013) and Holgersson (2013) show how firm characteristics can affect patenting activities.

Following their lead and choice of variables, we control for the firm's size, as this has an impact on the resources available to innovate and secure patent filings. We also control for firm age and the amount of money the firm devotes to research and development (R\&D) expenses. One would expect, for instance, that larger firms which are more established and spend more on $R \& D$ would generate a larger number of patents and a potentially larger number of citations

In addition to the firm characteristics, we also include two corporate governance characteristics. We consider the possibility that the CEO's background and the board's structure might influence the firm's propensity to patent abroad and internationalize its operations. To account for this, we focus on two measures that have been identified in the previous literature to account for this. The first is whether the CEO has had some form of educational experience abroad. Research has shown that $\mathrm{CEO} /$ founders with prior international experience can reduce the perceived psychic distance with the international markets, and their firms tend to internationalize faster (Lopez, Kundu and Ciravegna 2009, Oviatt and McDougall 2005). We therefore measure the proportion of time a CEO runs a firm with an overseas tertiary qualification.

The second measure that we consider is board independence, calculated as the proportion of independent directors on the board. Prior research has shown that board independence is linked to better performance of entrepreneurial firms (Daily, McDougall, Covin and Dalton 2002, Zahra, Neubaum and Huse 2000). Finally, we also include industry fixed effects to account for unobservable industry factors that may exist due to firms being in different industries. In addition, for any regression 
where we are analyzing foreign patent behavior, we also include a patent-office fixed effect to consider any potential variations in filing behavior arising from which office the patent is being filed at. Appendix I provides further details of how each of the above variables is operationalized.

The bottom of Table 1 shows the differences in the control variables across our three categories of firms. We find that for firm financial characteristics we find no significant differences except for firm age, with the BG group consisting of the youngest cohort of firms. As for the two corporate governance factors, we find that BG firms tend to be run for a greater proportion of the time by CEOs with international educational backgrounds (significant at the 1\% level) and that BG firms have marginally fewer independent directors compared to their TE and PD counterparts (at the 5\% and 10\% levels, respectively).

Table 2 provides the aggregate number of observations for each variable, along with overall means and standard deviations across the three cohorts of sample firms. To address non-normality in the distribution of some of our variables, we take the natural logarithm for the age of the patent, firm size, firm age, and R\&D expenditures in preparation for their usage in the multivariate regression analyses.

Insert Table 2 here.

Table 2 also provides a correlation matrix. In checking for multicollinearity between our variables we notice that two pairwise correlations are substantially higher than the rest of the correlations. There is a correlation of 0.934 between the speed of filing patents (\#3) and the firm's age (\#7). The reason for this high correlation is that they are partially derived from each other. The speed of filing a patent from the firm's inception is directly related to the firm's age. As such, we omit firm age when we examine speed of filing patents. The next highest correlation is between the time it 
takes a firm to internationalize after filing its first patent (\#4) and the patent's age (\#5) $(\rho=0.766)$. This arises for similar reasons (i.e., the time to internationalize relative to the firm's first patent filing is tied to the age of the patent). As for the remaining correlations that form our list of independent variables, none have high correlations with each other, implying multicollinearity will not pose a problem for our regression analyses.

Insert Table 3 here.

Beginning with hypothesis 1 , Table 3 reports the results from four crosssectional regressions. Each of these regression models focuses on a slightly different measure to capture patenting speed as the dependent variable. They are based on either the number of years it takes a firm to file patents relative to its inception date (Models 1a and 1b), or the number of years it takes to internationalize after filing a patent (Models 2a and 2b). If our first hypothesis is correct, then we should find that $\beta_{0}$ and $\beta_{1}$ in equation (1) should be positive, indicating that both PD and TE firms take longer to file patents.

The results in Table 3 do provide consistently strong support for our first hypothesis. In examining the determinants of the number of years it takes a firm from its founding to file a foreign patent (Model 1a in the table), both PD and TE firms take significantly longer (at the 0.001 level) than their BG counterparts. In addition to the treatment variables, two of the control variables (i.e., firm size and number of independent directors) are also positive and significant. The adjusted $\mathrm{R}^{2}$ for the regression Model 1a is 0.736 .

Similarly, in Model 1b, we examine the determinants of the number of years it takes a firm from its founding to file a Chinese patent. The main results show that both PD and TE firms take a significantly longer time (at the 0.001 level) than do BG 
firms. Again, this finding confirms our first hypothesis that BG firms will patent more quickly after their founding. In addition to the treatment variables, one of the control variables (i.e., firm size) has a positive and significant coefficient, and two of the control variables (i.e., R\&D and CEO international education) have negative and significant coefficients. The adjusted $\mathrm{R}^{2}$ for Model $1 \mathrm{~b}$ is 0.342 .

For Models 2a and 2b in Table 3, we address the second hypothesis and examine the number of years it takes to internationalize after filing a foreign patent. Since PD firms (by definition) do not internationalize, our analysis is restricted to comparing TE firms and BG firms. In Model 2a, we examine the determinants of the number of years it takes to internationalize after filing a foreign patent. The main result shows that TE firms take significantly longer (at the 0.001 level) to internationalize than their BG counterparts. In addition to the treatment variable, four of the control variables (i.e., firm size, firm age, $R \& D$, and the number of independent directors) are negative and statistically significant. The adjusted $\mathrm{R}^{2}$ for the regression Model 2a is 0.817 .

The results for Model $2 \mathrm{~b}$ are very similar to those of Model 2a. Specifically, TE firms take significantly longer to internationalize after obtaining a domestic Chinese patent than do BG firms - consistent with our second hypothesis. While the coefficients for size, age, and R\&D expenditures remain negative and significant, the independent directors' coefficient is positive and significant in the Chinese patent context. The adjusted $\mathrm{R}^{2}$ for Model $2 \mathrm{~b}$ is 0.726 . Overall, the results in Table 3 confirm both the first and second hypotheses by showing that BG firms file for foreign and domestic patents more rapidly than PD and TE firms and that BG firms internationalize their operations more rapidly after obtaining foreign or domestic patents than their TE counterparts. 
Appendix II reproduces Table 3 when utilizing an industry-adjusted measure for the speed of patenting as an alternative specification of the dependent variables used in the above models. For each dependent variable that expresses the number of years to filing patents (or between filing patents and internationalizing) we subtract the value by the average time it takes for the industry the firm is in. Doing so more directly controls for potential differences in speed-to-patenting between industries than simply including industry fixed effects. The results are qualitatively similar to those reported in Table 3, except that Model 2a no longer reports a significant result for the TE dummy variable.

In Table 4, we present regression results for testing our third and fourth hypotheses. For models $3 \mathrm{a}$ and $3 \mathrm{~b}$, we use a panel dataset. The dependent variable used is the number of foreign and domestic patents filed, respectively, on an annual basis. We also include one additional control variable to identify firms with foreign patents in Model 3b, as it may affect the likelihood of Chinese patents being filed. This is a dummy variable that takes the value of one if the company possesses a foreign patent, and zero otherwise. If our third hypothesis holds, we should find that both $\beta_{0}$ and $\beta_{1}$ of equation (1) should be negative, implying that BG firms file, on average, more patents per year than either TE or PD firms. The results for Model 3a (i.e., foreign patents) show that the estimated PD coefficient is negative and statistically significant at the 0.001 level, while the estimated TE coefficient is positive and insignificant. These findings align with our univariate results, which suggest our BG group sits somewhere between our PD and TE control groups in terms of the propensity to patent. In other words, we find no evidence supporting the third hypothesis that BG firms are naturally more innovative over a longer period than both PD and TE firms. For Model $3 b$ (i.e., domestic patents), the estimated PD 
coefficient is insignificant, while the estimated TE coefficient is positive and significant at the 0.05 level, again providing no evidence in support of the third hypothesis.

Insert Table 4 here.

In Models $4 \mathrm{a}$ and $4 \mathrm{~b}$ we return to using cross-sectional data and regress the number of citations per foreign and domestic patent, respectively, against the main treatment variables (i.e., PD and TE) and a set of control variables. Our fourth hypothesis suggest that $\mathrm{BG}$ firms will have a higher citation rate, implying $\beta_{0}$ and $\beta_{1}$ will be negative. The results for Model 4a (i.e., citations per foreign patent) show that the estimated TE coefficient is insignificant and the PD coefficient is only marginally significant at the $0.1 \%$ level, providing no support for the fourth hypothesis that BG firms are patenting more valuable knowledge outputs, which could then explain why they patent their innovations at earlier stages in their development. The results from Model 4b (i.e., citations per domestic patent) are also not supportive of the fourth hypothesis. While the estimated PD coefficient is insignificant, the estimated TE coefficient is positive and significant at 0.001 level, indicating TE firms having a greater level of citations for their patents than BG firms.

Among the control variables, an interesting result emerges for the estimated coefficient of patent age. It is negative and significant when one might expect a positive relationship, as the older the patent is, the more citations it is likely to attract. However, further analysis reveals that patents filed in the earlier part of our study period (and particularly prior to 2006) attract very few citations, leading to this negative relationship. Citations of patents from Chinese companies seem to only be prevalent in more recent years. This may be reflective of China joining the WTO, 
with older patents possibly being less known or not considered as important as more recent ones. Finally, compared to Table 3, our models' explanatory power is relatively small, with the $\mathrm{R}^{2}$ values in Table 4 ranging from a low of 0.068 in Model 4a to a high of 0.130 in Model 3a. These differences in $\mathrm{R}^{2}$ values suggest that it is more difficult to explain cross-sectional differences in patents' quality than cross-sectional differences in the quantity of patents (Lanjouw and Schankerman 2004, Squicciarini, Dernis and Criscuolo 2013).

Finally, in Appendix III we reproduce Table 4 where we industry-adjust each of the dependent variables used in the above models. The results, again, are qualitatively similar.

\section{DISCUSSION AND CONTRIBUTIONS}

In this study, we hand-collect a set of Chinese SMEs to examine the characteristics that allow a subset of such firms that are relatively young and have aspirations from the outset to internationalize (i.e., BGs) to transform themselves into international entrepreneurs rapidly. We argue that these BGs will distinguish themselves in their attempt to become IEs through the early acquisition of high-quality patents in both the domestic and international markets. Specifically, we expect that our sample of BGs will file for patents at an earlier stage in their development relative to non-BG firms, including both purely domestic firms (PD) and traditional exporting (TE) firms. We associate this early acquisition of patents by BGs to their initial intentions to internationalize, which are not present for PD or TE firms. Applying the theory of planned behavior, we expect BGs to action their intent to internationalize their operations more quickly than non-BGs after receiving their first domestic or foreign patent. In addition to the initial speed of patenting (and internationalizing), we also 
examine the ongoing rate of patent production and the quality of those patents between BGs and non-BGs. If BGs have a faster speed-to-patenting from their founding, it may be the case that they are generally more knowledge-focused and innovative than other firms, leading them to patent more frequently. We test if this is true by examining whether BGs generate a higher quantity of patents, as well as a higher average quality of patents (based on citations per patent) than their non-BG counterparts.

Unlike many previous studies, our hand-collected database allows us to directly test these hypotheses because of our ability to identify BG firms on an exante basis. Our database also allows us to help fill two significant holes in the current literature, as described in Cavusgil and Knight (2015) (i.e., the lack of longitudinal studies and the lack of emerging market studies). We manually examine annual reports and other publicly available records for direct evidence that an SME intends to internationalize from its original founding - a key attribute of being a BG firm. Therefore, we use the firm's own stated intentions as part of our definition of young aspiring globals (YAGs) as BGs. Once identified, we can track the early-stage strategies that these firms use to achieve the status of international entrepreneurs (IE).

Our empirical findings from the hand-collected sample of Chinese firms confirm that BGs (YAGs) file for patents at an earlier stage of their development than non-BGs (i.e., both PDs and TEs). These patents registrations signal the intent of the entrepreneurs to approach the global market for their venture. We also find that BGs internationalize their operations more quickly than non-BGs, after receiving a domestic or foreign patent. The extant literature on BGs internationalization highlights the limitation of retrospectively checking with entrepreneurs whether they had intended to access international markets at the time of inception (Hewerdine and 
Welch 2013). By applying the intent-behavior aspect of the theory of planned behavior (TPB) and using patent information, we can identify whether these ventures are indeed BGs or, as Hennart (2014), accidental internationalists.

Concerning what happens to knowledge-focused BGs when they grow up, we find that these firms are, in the longer run, neither more innovative nor produce more valuable innovations (as captured through their average patent rates over time and citations per patent). In other words, we associate the initial, fast pace of patenting as being part of a forward-looking, strategic decision by BGs to internationalize, rather than due to them merely patenting more frequently. These findings suggest that while these BGs are reliant on developing their knowledge capital and are innovative at inception, they lose this innovation over time, thereby allowing traditional firms to catch-up. Hence, while the initial internationalizing attempts are planned, subsequent internationalization may be reactive, as evidenced by the lack of innovation. Recent studies suggest that maturing BGs can enhance their knowledge and technological innovation through acquisitions, but these benefits also seem to decline after a while (Øyna, Almor, Elango and Tarba 2018).

Finally, our findings show that due to institutional and economic development still in its infancy, YAGs or BGs from emerging markets may be slower in achieving their objectives than BGs from developed countries. Specifically, our study looks at BGs from China, a country transitioning from a centrally-planned command economy to a market economy. Recent studies highlight the rigidity of the institutional environment in transition economies, despite efforts to encourage an entrepreneurial culture (Dang, Jasovska and Rammal 2020). Table 5 summarizes the key findings of this study. 
Insert Table 5 here.

Historically, Chinese State-owned enterprises were encouraged to internationalize, but China's WTO membership has also increased international market opportunities for innovative private SMEs. The high number of patent registration since the membership confirms this, as does China's fast rise in the Global Innovation Index, where they are ranked 14 in 2020 (Global Innovation Index 2020). Hence, our findings highlight that trade openness and membership of supranational organizations has been the catalyst for the growth and internationalization of Chinese entrepreneurial ventures.

We contribute to the literature in a number of ways. First, we propose that BG originating from an emerging economy (YAGs) that places institutional constraints on internationalizing will not be able to meet their objectives as quickly as those in more developed markets. Second, in contrast to previous studies, we directly examine sample firms for evidence of their intention to internationalize at their founding. Our findings demonstrate the link between entrepreneurial intention and action to internationalize, which is best explained by the theory of planned behavior (TPB). By doing so, we contribute to the debate on whether entrepreneurs' intention to internationalize should be measured from the time of their inception or prior to that. We also demonstrate how TPB can be applied in conjunction with patent data to capture BG founders' intention to internationalize and the actions they take to achieve this. We find that the intention to internationalize before the inception explains entrepreneurs' action to protect their innovation through patent registration at both home and internationally. 
This study helps to fill two gaps in the extant literature as described in Cavusgil and Knight (2015); specifically, the need for longitudinal data to examine (p. 12) 'what happens to born global firms when they grow up?' and the need for emerging market data to examine 'distinctions between born global firms from the advanced economies and those from emerging markets.'

Overall, this study contributes to a broader understanding of knowledge capital, innovation, and International Business by examining the distinctive characteristics and strategies of emerging-market BGs. We propose the term YAGs to describes BGs from merging economies that signal their intention to internationalize from inception by registering patents, rapidly internationalize, and operate under infant and evolving institutional environments. Our findings and conclusions also add to the literature focusing on international entrepreneurship in the increasingly important emerging economy context (Kiss, Danis and Cavusgil 2012).

\section{FUTURE RESEARCH AGENDA}

Our study provides insights into the internationalization patterns of IE. We find that while our sample of BG firms or YAGs internationalize early, and aggressively protect their intellectual property at an early stage, this tapers off in later years with their innovations being not valued any higher than those of TEs. We also demonstrate how patent registration and citations can be used to capture the crossborder activities of entrepreneurs over time. This addresses a gap in the literature where most studies capture IE firms' internationalization patterns at a particular point in time, rather than over time, and opens possible avenues for future research. In particular, this provides avenues for future studies to look at how early 
internationalizing firms behave at their inception and early stages and in the longer term.

What we do not examine, and is an avenue for future research, is whether the speed of patenting has an impact on firm performance. Those YAGs firms that aim to patent at a faster rate may enjoy economic benefits over those firms that that take longer to patent their innovations, particularly if this implies their competition has more time to 'catch up' on any competitive advantage that their innovation may have provided.

\section{References}

Acedo, F.J. and Jones, M.V. (2007), "Speed of internationalization and entrepreneurial cognition: Insights and a comparison between international new ventures, exporters and domestic firms", Journal of World Business, Vol. 42 No. 3, pp. 236-52.

Acs, Z.J., Braunerhjelm, P., Audretsch, D.B. and Carlsson, B. (2009), "The knowledge spillover theory of entrepreneurship", Small Business Economics, Vol. 32 No. 1, pp. 15-30.

Ajzen, I. (1985), "From intentions to actions: A theory of planned behavior", in Kuhl, J. and Beckman, J. (Eds.), Action control: From cognition to behaviors, Springer, New York, pp. 11-39.

Ajzen, I. (1991), "The theory of planned behavior", Organizational Behavior and Human Decision Processes, Vol. 50 No. 2, pp. 179-211.

Ajzen, I. (2002), "Perceived behavioral control, self-efficacy, locus of control, and the theory of planned behavior", Journal of applied social psychology, Vol. 32 No. 4, pp. 665-83.

Al-Laham, A., Amburgey, T.L. and Baden-Fuller, C. (2010), "Who is My Partner and How Do We Dance? Technological Collaboration and Patenting Speed in US Biotechnology", British Journal of Management, Vol. 21 No. 3, pp. 789-807. Andries, P. and Faems, D. (2013), "Patenting activities and firm performance: does firm size matter?", Journal of Product Innovation Management, Vol. 30 No. 6, pp. 1089-98.

Baum, M., Schwens, C. and Kabst, R. (2015), "A latent class analysis of small firms' internationalization patterns", Journal of World Business, Vol. 50 No. 4, pp. 754-68. $\mathrm{Bu}, \mathrm{J}$. and Cuervo-Cazurra, A. (2020), "Informality costs: Informal entrepreneurship and innovation in emerging economies", Strategic Entrepreneurship Journal, Vol. 14 No. 3, pp. 329-68.

Buccieri, D., Javalgi, R.G. and Cavusgil, E. (2020), "International new venture performance: Role of international entrepreneurial culture, ambidextrous innovation, 
and dynamic marketing capabilities", International Business Review, Vol. 29 No. 2, pp. 101639.

Cabrilo, S. and Dahms, S. (2018), "How strategic knowledge management drives intellectual capital to superior innovation and market performance", Journal of Knowledge Management, Vol. 22 No. 3, pp. 621-48.

Carayannis, E.G., Ferreira, J.J.M. and Fernandes, C. (2021), "A prospective retrospective: conceptual mapping of the intellectual structure and research trends of knowledge management over the last 25 years", Journal of Knowledge Management, Vol. ahead-of-print.

Cavusgil, S.T. and Knight, G. (2009), Born Global Firms: A New International Enterprise, Business Expert Press, LLC, New York.

Cavusgil, S.T. and Knight, G. (2015), "The born global firm: An entrepreneurial and capabilities perspective on early and rapid internationalization", Journal of International Business Studies, Vol. 46, pp. 3-16.

Choquette, E., Rask, M., Sala, D. and Schröder, P. (2017), "Born Globals - Is there fire behind the smoke?", International Business Review, Vol. 26 No. 3, pp. 448-60. Ciravegna, L., Kuivalainen, O., Kundu, S. and Lopez, L.E. (2018), "The antecedents of early internationalization: A configurational perspective", International Business Review, Vol. 27 No. 6, pp. 1200-12.

Ciravegna, L., Majano, S.B. and Zhan, G. (2014), "The inception of internationalization of small and medium enterprises: The role of activeness and networks", Journal of Business Research, Vol. 67 No. 6, pp. 1081-89.

Coviello, N. (2015), "Re-thinking research on born globals", Journal of International Business Studies, Vol. 46, pp. 17-26.

Coviello, N., Kano, L. and Liesch, P.W. (2017), "Adapting the Uppsala model to a modern world: Macro-context and microfoundations", Journal of International Business Studies, Vol. 48 No. 9, pp. 1151-64.

Coviello, N.E. and Jones, M.V. (2004), "Methodological issues in international entrepreneurship research", Journal of Business Venturing, Vol. 19, pp. 485-508.

Daily, C.M., McDougall, P.P., Covin, J.G. and Dalton, D.R. (2002), "Governance and Strategic Leadership in Entrepreneurial Firms", Journal of Management, Vol. 28 No. 3, pp. 387-412.

Dang, Q.T., Jasovska, P. and Rammal, H.G. (2020), "International businessgovernment relations: The risk management strategies of MNEs in emerging economies", Journal of World Business, Vol. 55 No. 1, pp. 101042.

De Rassenfosse, G. (2012), "How SMEs exploit their intellectual property assets:

evidence from survey data", Small Business Economics, Vol. 39 No. 2, pp. 437-52.

Dimitratos, P., Buck, T., Fletcher, M. and Li, N. (2016), "The motivation of international entrepreneurship: The case of Chinese transnational entrepreneurs", International Business Review, Vol. 25 No. 5, pp. 1103-13.

Dimitratos, P., Voudouris, I., Plakoyiannaki, E. and Nakos, G. (2012), "International entrepreneurial culture- Toward a comprehensive opportunity-based operationalization of international entrepreneurship", International Business Review, Vol. 21 No. 4, pp. 708-21.

Dow, D. (2017), "Born global firms and accidental internationalists: Has Hennart (2014) opened a can of worms?", Review of International Business and Strategy, Vol. 27 No. 3, pp. 286-307.

Elson, J.A. and Weidinger, A. (2019), "Entrepreneurial intention and regional internationalization in China", Small Business Economics, Vol. 53, pp. 1001-15. 
European Commission. (2020), "What is an SME?", available at:

http://ec.europa.eu/growth/smes/business-friendly-environment/sme-

definition/index en.htm (accessed 24 February 2020).

Falahat, M., Knight, G. and Alon, I. (2018), "Orientations and capabilities of born global firms from emerging markets", International Marketing Review, Vol. 35 No. 6, pp. 936-57.

Gieure, C., Benavides-Espinosa, M. and Roig-Dobón, S. (2020), "The entrepreneurial process: The link between intentions and behavior", Journal of Business Research, Vol. 12, pp. 541-48.

Global Innovation Index. (2020), "Global Innovation Index 2020: Who will Finance Innovation?", available at: https://www.globalinnovationindex.org/Home (accessed 5 October 2020).

Griliches, Z. (1984), R\&D, Patents, and Productivity, University of Chicago Press, Chicago.

Hennart, J.F. (2014), "The accidental internationalists: a theory of born globals", Entrepreneurship Theory and Practice, Vol. 38 No. 1, pp. 117-35.

Hewerdine, L. and Welch, C. (2013), "Are international new ventures really new? A process study of organizational emergence and internationalization", Journal of World Business, Vol. 48 No. 4, pp. 466-77.

Holgersson, M. (2013), "Patent management in entrepreneurial SMEs: a literature review and an empirical study of innovation appropriation, patent propensity, and motives", $R \& D$ Management, Vol. 43 No. 1, pp. 21-36.

Hsu, D.H. and Ziedonis, R.H. (2013), "Resources as Dual Sources of Advantage: Implications for Valuing Entrepreneurial-Firm Patents", Strategic Management Journal, Vol. 34, pp. 761-81.

Ivus, O. (2015), "Does stronger patent protection increase export variety? Evidence from US product-level data", Journal of International Business Studies, Vol. 46, pp. 724-31.

Jaffe, A. and Trajtenberg, M. (2002), Patents, Citations and Innovations: A Window on the Knowledge Economy, MIT Press, Cambridge, MA.

Jiang, G., Kotabe, M., Zhang, F., Hao, A.W., Paul, J. and Wang, C.L. (2020), "The determinants and performance of early internationalizing firms: A literature review and research agenda", International Business Review, Vol. 29 No. 4, pp. 101662. Jiang, N. and Kattuman, P.A. (2012), "China's WTO Accession and Long-Term Profitability of Chinese Firms", International Journal of the Economics of Business, Vol. 19 No. 1, pp. 53-73.

Johanson, J. and Vahlne, J.-E. (1977), "The Internationalization Process of the FirmA Model of Knowledge Development and Increasing Market Commitment", Journal of International Business Studies, Vol. 8, pp. 23-32.

Jones, M.V., Coviello, N. and Tang, Y.K. (2011), "International Entrepreneurship Research (1989-2009): A domain ontology and thematic analysis", Journal of Business Venturing, Vol. 26, pp. 632-59.

Kafouros, M.I., Buckley, P.J., Sharp, J.A. and Wang, C. (2008), "The role of internationalization in explaining innovation performance", Technovation, Vol. 28 No. 1-2, pp. 63-74.

Kautonen, T., Gelderen, M. and Fink, M. (2015), "Robustness of the theory of planned behavior in predicting entrepreneurial intentions and actions", Entrepreneurship Theory and Practice, Vol. 39 No. 3, pp. 655-74. 
Kiss, A.N., Danis, W.M. and Cavusgil, S.T. (2012), "International entrepreneurship research in emerging economies: A critical review and research agenda", Journal of Business Venturing, Vol. 27 No. 2, pp. 266-90.

Knight, G.A. and Cavusgil, S.T. (2004), "Innovation, organizational capabilities, and the born-global firm", Journal of International Business Studies, Vol. 35, pp. 124-41. Knight, G.A. and Liesch, P.W. (2016), "Internationalization: From incremental to born global", Journal of World Business, Vol. 51 No. 1, pp. 93-102.

Krueger, N.F. and Carsrud, A.L. (1993), "Entrepreneurial intentions: applying the theory of planned behaviour", Entrepreneurship \& Regional Development, Vol. 5 No. 4, pp. 315-30.

Lamotte, O. (2015), "Early Internationalization of New Ventures from Emerging Countries: The Case of Transition Economies",M@N@GEMENT, Vol. 18 No.1, pp. 8-30.

Lanjouw, J.O. and Schankerman, M. (2004), "Patent Quality and Research Productivity: Measuring Innovation with Multiple Indicators", The Economic Journal, Vol. 114 No. 495, pp. 441-65.

Lee, R., Lee, J.-H. and Garrett, T.C. (2019), "Synergy effects of innovation on firm performance", Journal of Business Research, Vol. 99, pp. 507-15.

Li, X. (2012), "Behind the recent surge of Chinese patenting: An institutional view", Research Policy, Vol. 41 No. 1, pp. 236-49.

Liesch, P.W., Welch, L.S. and Buckley, P.J. (2011), "Risk and Uncertainty in Internationalisation and International Entrepreneurship Studies: Review and Conceptual Development", Management International Review, Vol. 51, pp. 851-73.

Lin, S., Mercier-Suissa, C. and Salloum, C. (2016), "The Chinese born globals of the Zhejiang province: A study on the key factors for their rapid internationalization", Journal of International Entrepreneurship, Vol. 14 No. 1, pp. 75-95.

Lin, S. and Si, S. (2019), "The influence of exploration and exploitation on born globals' speed of internationalization", Management Decision, Vol. 57 No. 1, pp. 193-210.

Liu, W., Tan, R., Li, Z., Cao, G. and Yu, F. (2021), "A patent-based method for monitoring the development of technological innovations based on knowledge diffusion", Journal of Knowledge Management, Vol. 25 No. 2, pp. 380-401.

Lopez, L.E., Kundu, S.K. and Ciravegna, L. (2009), "Born global or born regional? Evidence from an exploratory study in the Costa Rican software industry", Journal of International Business Studies, Vol. 40, pp. 1228-38.

Lortie, J. and Castogiovanni, G. (2015), "The theory of planned behavior in Entrepreneurship Research: What we know and future directions", International Entrepreneurship and Management Journal, Vol. 11 No. 4, pp. 935-57.

Mahmood, I.P. and Singh, J. (2003), "Technological dynamism in Asia", Research Policy, Vol. 32, pp. 1031-54.

Marquis, C. and Qiao, K. (2020), "Walking from Mao's Dream: Communist Ideological Imprinting and the Internationalization of Entrepreneurial Ventures in China", Administrative Science Quarterly, Vol. 65 No. 3, pp. 795-830.

McDougall, P.P. (1989), "International versus Domestic Entrepreneurship: New Venture Strategic Behavior and Industry Structure", Journal of Business Venturing, Vol. 4, pp. 387-400.

McKinsey \& Company. (1993), Emerging exporters: Australia's high value-added manufacturing exporters, Australian Manufacturing Council, Melbourne.

Munir, H., Jiangfei, C. and Ramzan, S. (2019), "Personality traits and theory of planned behavior comparison of entrepreneurial intentions between an emerging 
economy and a developing country", International Journal of Entrepreneurial Behavior \& Research, Vol. 25 No. 3, pp. 554-80.

Muralidharan, E. and Pathak, S. (2017), "Informal institutions and international entrepreneurship", International Business Review, Vol. 26 No. 2, pp. 288-302.

Naudé, W. and Rossouw, S. (2010), "Early international entrepreneurship in China:

Extent and determinants", Journal of International Entrepreneurship, Vol. 8, pp. 87111.

Nieto, M.J. and Rodriguez, A. (2011), "Offshoring of R\&D: Looking abroad to improve innovation performance", Journal of International Business Studies, Vol. 42, pp. 345-61.

Nonaka, I. and Takeuchi, H. (1995), The knowledge creating company: How Japanese companies create the dynamics of innovation, Oxford University Press, New York.

Obschonka, M., Silbereisen, R.K., Canter, U. and Goethner, M. (2015), "Entrepreneurial Self-Identify: Predictors and Effects Within the Theory of Planned Behavior Framework", Journal of Business and Psychology, Vol. 30 No. 4, pp. 77394.

Onetti, A., Zucchella, A., Jones, M.V. and McDougall-Covin, P. (2012),

"Internationalization, innovation and entrepreneurship: Business models for new technology-based firms", Journal of Management and Governance, Vol. 16 No. 3, pp. 337-68.

Oviatt, B.M. and McDougall, P.P. (1994), "Toward a theory of international new ventures", Journal of International Business Studies, Vol. 25 No. 1, pp. 45-64.

Oviatt, B.M. and McDougall, P.P. (2005), "The internationalization of entrepeneurship", Journal of International Business Studies, Vol. 36 No. 1, pp. 2-8. Øyna, S., Almor, T., Elango, B. and Tarba, S.Y. (2018), "Maturing born globals and their acquisitive behaviour", International Business Review, Vol. 27 No. 3, pp. 71425.

Pathak, S., Xavier-Oliveira, E. and Laplume, A.O. (2013), "Influence of intellectual property, foreign investment, and technological adoption on technology entrepreneurship", Journal of Business Research, Vol. 66 No. 10, pp. 2090-101. Quan, X., Xiao, H., Ji, Q. and Zhang, J. (2021), "Can innovative knowledge management platforms lead to corporate innovation? Evidence from academician workstations in China", Journal of Knowledge Management, Vol. 25 No. 1, pp. 117 35 .

Ramadani, V., Abazi-Alili, H., Dana, L.-P., Rexhepi, G. and Ibraimi, S. (2017), "The impact of knowledge spillovers and innovation on firm-performance: findings from the Balkans countries", International Entrepreneurship and Management Journal, Vol. 13 No. 1, pp. 299-325.

Reitzig, M. and Puranam, P. (2009), "Value appropriation as an organizational capability: The case of IP protection through patents", Strategic Management Journal, Vol. 30 No. 7, pp. 765-89.

Ren, S., Eisingerich, A.B. and Tsai, H.-T. (2015), "How do marketing, research and development capabilities, and degree of internationalization synergistically affect the innovation performance of small and medium-sized enterprises (SMEs)? A panel data study of Chinese SMEs", International Business Review, Vol. 24 No. 4, pp. 642-51. Rennie, M.W. (1993), "Global Competitiveness: born global", The McKinsey Quarterly, Vol. 4, pp. 45-52. 
Rodriguez, A. and Nieto, M.J. (2016), "Does R\&D offshoring lead to SME growth? Different governance modes and the mediating role of innovation", Strategic Management Journal, Vol. 37 No. 8, pp. 1734-53.

Ruzzier, M., Douglas, E.J., Ruzzier, M.K. and Hojnik, J. (2020), "International Entrepreneurial Orientation and the Intention to Internationalize", Sustainability, Vol. 12 No. 4, pp. 5647.

Sachs, J.D. and Woo, W.T. (2003), "China's Economic Growth after WTO Membership", Journal of Chinese Economic and Business Studies, Vol. 1 No. 1, pp. $1-31$.

Salidjanova, N. (2011), Going Out: An Overview of China's Outward Foreign Direct Investment, US-China Economic \& Security Review Commission, USCC Staff Research Report.

Schwens, C., Zapkau, F.B., Bierwerth, M., Isidor, R., Knight, G. and Kabst, R. (2018), "International Entrepreneurship: A Meta-Analysis on the Internationalization and Performance Relationship", Entrepreneurship Theory and Practice, Vol. 42 No. 5, pp. 734-68.

Siegel, D.S. and Renko, M. (2012), "The role of market and technological knowledge in recognizing entrepreneurial opportunities", Management Decision, Vol. 50 No. 5, pp. 797-816.

Squicciarini, M., Dernis, H. and Criscuolo, C. (2013), Measuring Patent Quality: Indicators of Technological and Economic Value, OECD Publishing, OECD Science, Technology and Industry Working Papers: 2013/03.

Stoianoff, N.P. (2012), "The Influence of the WTO over China's Intellectual Property Regime", Sydney Law Review, Vol. 34 No. 1, pp. 65-89.

Symeonidou, N., Bruneel, J. and Autio, E. (2017), "Commercialization strategy and internationalization outcomes in technology-based new ventures", Journal of Business Venturing, Vol. 32 No. 2, pp. 302-17.

Szirmai, A., Naudé, W. and Goedhuys, M. (2011), "Entrepreneurship, Innovation, and Economic Development: An Overview", in Szirmai, A., Wim, N. and Goedhuys, M. (Eds.), Entrepreneurship, Innovation, and Economic Development, Oxford University Press, New York, pp. 3-32.

Tekin, E., Ramadani, V. and Dana, L.-P. (2021), "Entrepreneurship in Turkey and other Balkan countries: are there opportunities for mutual co-operation through internationalisation?", Review of International Business and Strategy, Vol. 31 No. 2, pp. 297-314.

Terjesen, S., Hessels, J. and Li, D. (2016), "Comparative International

Enterpreneurship: A Review and Research Agenda", Journal of Management, Vol. 42 No. 1, pp. 299-344.

Toms, S., Wilson, N. and Wright, M. (2020), "Innovation, intermediation, and the nature of entrepreneurship: A historical perspective", Strategic Entrepreneurship Journal, Vol. 14 No. 1, pp. 105-21.

UNCTAD. (2018), "UNCTADStat. United Nations Conference on Trade and Development", available at: http://unctadstat.unctad.org (accessed 14 September 2018).

van Praag, C.M. and Versloot, P.H. (2007), "What is the value of entrepreneurship? A review of recent research", Small Business Economics, Vol. 29 No. 4, pp. 351-82.

Wei, T., Clegg, J. and Ma, L. (2015), "The conscious and unconscious facilitating role of the Chinese government in shaping the internationalization of Chinese MNCs", International Business Review, Vol. 24 No. 2, pp. 331-43. 
WIPO. (2018), "China drives international patent applications to record heights; demands rising for Trademark and Industrial Design protection", World Intellectual Property Organization Press Release PR/2018/816, Vol. March 21, pp. https://www.wipo.int/pressroom/en/articles/2018/article_0002.html.

Woetzel, J., Chen, Y., Manyika, J., Roth, E., Seong, J. and Lee, J. (2015), "The China Effect on Global Innovation", McKinsey \& Company, Vol. October.

Wu, J., Wang, C., Hong, J., Piperopoulos, P. and Zhuo, S. (2016), "Internationalization and innovation performance in emerging market enterprises: The role of host-country institutional development", Journal of World Business, Vol. 51 No. 2, pp. 251-63.

Yamakawa, Y., Khavul, S., Peng, M.W. and Deeds, D.L. (2013), "Venturing from Emerging Economies", Strategic Entrepreneurship Journal, Vol. 7 No. 3, pp. 181-96. Zahra, S. (2005), "A theory of international new ventures: A decade of research", Journal of International Business Studies, Vol. 36 No. 1, pp. 20-28.

Zahra, S.A., Neubaum, D.O. and Huse, M. (2000), "Entrepreneurship in Medium-Size Companies: Exploring the Effects of Ownership and Governance Systems", Journal of Management, Vol. 26 No. 5, pp. 947-76.

Zaim, H., Ramadani, V., Dinibutun, S.R., Gërguri-Rashiti, S. and Said, D.S. (2021), "Knowledge management and human resources performance: evidence from Turkish family businesses", Journal of Family Business Management, Vol. ahead-of-print No. https://doi.org/10.1108/JFBM-11-2020-0108.

Zander, I., McDougall-Covin, P. and Rose, E.L. (2015), "Born globals and international business: Evolution of a field of research", Journal of International Business Studies, Vol. 46, pp. 27-35.

Zhang, X., Ma, X., Wang, Y., Li, X. and Huo, D. (2016), "What drives the internationalization of Chinese SMEs? The joint effects of international entrepreneurship characteristics, network ties, and firm ownership", International Business Review, Vol. 25 No. 2, pp. 522-34.

Zhou, L. and Wu, A. (2014), "Earliness of internationalizaton and performance outcomes: Exploring the moderating effects of venture age and international commitment", Journal of World Business, Vol. 49 No. 1, pp. 132-42.

Zia, N.U. (2020), "Knowledge-oriented leadership, knowledge management behaviour and innovation performance in project-based SMEs. The moderating role of goal orientations", Journal of Knowledge Management, Vol. 24 No. 8, pp. 181939. 
Table 1: Summary statistics of patent, citation and firm-level information.

\begin{tabular}{lllll}
\hline & $\begin{array}{l}\text { Chinese } \\
\text { Born Globals } \\
\text { YAGs }\end{array}$ & $\begin{array}{l}\text { Purely } \\
\text { Domestic } \\
\text { SMEs }\end{array}$ & $\begin{array}{l}\text { Traditional } \\
\text { Exporters }\end{array}$ & Total \\
\hline Number of firms & 43 & 99 & 29 & 171 \\
Number of patents & 982 & 1,289 & 1,322 & 3,593 \\
$\quad$ Number of foreign patents & 171 & 25 & 211 & 407 \\
$\quad$ Number of Chinese patents & 811 & 1,264 & 1,111 & 3,186
\end{tabular}

\section{Patent and Citation Information \\ Number of patents filed \\ Average number of foreign patents filed per firm year \\ Average number of Chinese patents filed per firm year \\ Number of citations per patent \\ Average number of citations per foreign patent \\ Average number of citations per Chinese patent \\ Speed of filing patents \\ Average \# of years from inception to filing a foreign patent \\ Average \# of years from inception to filing Chinese patent}

\begin{abstract}
Time between patenting and internationalizing

Average \# of years from filing a foreign patent to internationalizing

Average \# of years from filing a Chinese patent to internationalizing
\end{abstract}

Average patent age (as of 2015)

\section{Firm characteristics}

\section{Financials}

Average total assets (USD mil)

at inception

Average firm age (year)

Average R\&D expense (USD mil)

\section{Corporate Governance}

Average number of independent directors

Average proportion of time a firm is run by a CEO with international education (in \%)

\begin{tabular}{|c|c|c|}
\hline 0.26 & 0.02 & 0.53 \\
\hline & $\left(-0.25^{* * *}\right)$ & $\left(0.27^{*}\right)$ \\
\hline 1.31 & 0.91 & 2.75 \\
\hline & $\left(-0.40^{* * *}\right)$ & $\left(1.44^{* * *}\right)$ \\
\hline 5.32 & 5.52 & 5.96 \\
\hline & $(0.20)$ & $(0.64)$ \\
\hline 0.85 & 0.55 & 1.57 \\
\hline & $\left(0.29^{* * *}\right)$ & $\left(0.73^{* * *}\right)$ \\
\hline 6.32 & 10.72 & 9.20 \\
\hline & $\left(4.40^{* * *}\right)$ & $\left(2.88^{* * *}\right)$ \\
\hline 7.25 & 11.26 & 10.84 \\
\hline & $\left(4.01^{* * *}\right)$ & $\left(3.59^{* * *}\right)$ \\
\hline 0.95 & & 5.46 \\
\hline & & $\left(3.45^{* * *}\right)$ \\
\hline 1.35 & & 4.05 \\
\hline & & $\left(3.15^{* * *}\right)$ \\
\hline 1.30 & 1.43 & 1.63 \\
\hline & $\left(0.13^{* * *}\right)$ & $\left(0.33^{* * *}\right)$ \\
\hline 18.39 & 19.06 & 17.42 \\
\hline & $(0.67)$ & $(-0.97)$ \\
\hline 7.75 & 11.41 & 11.67 \\
\hline & $\left(3.66^{* * *}\right)$ & $\left(3.92^{* * *}\right)$ \\
\hline 1.84 & 1.83 & 1.51 \\
\hline & $(-0.01)$ & $\left(-0.33^{+}\right)$ \\
\hline 2.70 & 2.81 & 2.82 \\
\hline & $\left(0.11^{*}\right)$ & $\left(0.12^{+}\right)$ \\
\hline 9.19 & 4.55 & 2.18 \\
\hline & $\left(-4.64^{* * *}\right)$ & $\left(-7.01^{* * *}\right)$ \\
\hline
\end{tabular}

Speed of filing patents refers to the average number of years it takes a firm to file its first patent relative to when the company is founded. Time between patenting and exporting refers to the average time it takes from when a firm files its first patent to when it internationalizes. Figures in parentheses represent the difference in means between the category (either Purely Domestic SMEs or Traditional Exporters) against Born Globals, with the stars representing statistical significance from conducting two-tail tests in differences.

${ }^{+} p<0.1,{ }^{*} p<0.05,{ }^{* *} p<0.01,{ }^{* * *} p<0.001$ 
Table 2: Descriptive statistics and correlations of the variables.

\begin{tabular}{|c|c|c|c|c|c|c|c|c|c|c|c|c|c|}
\hline \multirow[t]{2}{*}{ Variable } & \multirow[t]{2}{*}{ Obs } & \multicolumn{2}{|c|}{ Summary statistics } & \multicolumn{10}{|c|}{ Correlation coefficients } \\
\hline & & Mean & Std. dev. & $(1)$ & $(2)$ & $(3)$ & $(4)$ & $(5)$ & $(6)$ & $(7)$ & $(8)$ & (9) & $(10)$ \\
\hline (1) Number of patents filed & 2,394 & 1.487 & 4.646 & 1 & & & & & & & & & \\
\hline (2) Citations per patents & 3,593 & 1.513 & 4.278 & $0.114^{* * *}$ & 1 & & & & & & & & \\
\hline (3) Speed of filing patents & 3,593 & 9.867 & 4.434 & $-0.259^{* * *}$ & $-0.062^{* * *}$ & 1 & & & & & & & \\
\hline (4) Filing to internationalizing & 2,303 & 3.220 & 3.772 & $0.567^{* * *}$ & $0.059^{* *}$ & $-0.434^{* * *}$ & 1 & & & & & & \\
\hline (5) Ln(Patent's age) & 3,593 & 1.469 & 0.618 & $0.260^{* * *}$ & -0.013 & $-0.433^{* * *}$ & $0.766^{* * *}$ & 1 & & & & & \\
\hline (6) Ln(Firm size) & 1,517 & 3.927 & 1.568 & $0.180^{* * *}$ & $-0.032^{+}$ & $0.284^{* * *}$ & $-0.318^{* * *}$ & $-0.440^{* * *}$ & 1 & & & & \\
\hline (7) Ln(Firm age) & 2,243 & 2.160 & 0.709 & $0.066^{* *}$ & $-0.070^{* * *}$ & $0.934^{* * *}$ & $-0.478^{* * *}$ & $-0.460^{* * *}$ & $0.408^{* * *}$ & 1 & & & \\
\hline (8) $\operatorname{Ln}(\mathrm{R} \& D$ expense) & 786 & -0.114 & 1.445 & $0.167^{* * *}$ & -0.019 & $0.097^{* * *}$ & $-0.518^{* * *}$ & $-0.346^{* * *}$ & $0.517^{* * *}$ & $0.117^{* * *}$ & 1 & & \\
\hline (9) Number of independent directors & 1,609 & 2.787 & 0.898 & $0.049^{+}$ & $0.067^{* * *}$ & -0.002 & $-0.056^{+}$ & 0.001 & $0.087^{* * *}$ & 0.023 & $0.141^{* * *}$ & 1 & \\
\hline (10) CEO has international education & 1,625 & 0.0517 & 0.221 & $-0.057^{*}$ & -0.001 & -0.026 & $-0.175^{* * *}$ & $-0.128 * * *$ & $-0.056^{*}$ & $-0.143^{* * *}$ & -0.014 & 0.015 & 1 \\
\hline
\end{tabular}

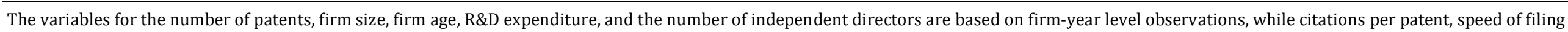
patents, time between patenting and internationalizing, and patent age are based on patent-level observations.

${ }^{+} p<0.1, \quad{ }^{*} p<0.05,{ }^{* *} p<0.01,{ }^{* * *} p<0.001$. 
Table 3: Multivariate analysis of speed-of-patenting.

\begin{tabular}{|c|c|c|c|c|}
\hline Variables & Model 1a & Model 1b & Model 2a & Model 2b \\
\hline Dependent variable: & $\begin{array}{l}\text { \# years from inception } \\
\text { to filing a foreign patent }\end{array}$ & $\begin{array}{l}\text { \# years from inception } \\
\text { to filing a Chinese } \\
\text { patent }\end{array}$ & $\begin{array}{l}\text { \# years between filing } \\
\text { foreign patent and } \\
\text { internationalizing }\end{array}$ & $\begin{array}{l}\text { \# years between filing } \\
\text { Chinese patent and } \\
\text { internationalizing }\end{array}$ \\
\hline \multicolumn{5}{|l|}{ Independent variables } \\
\hline \multirow[t]{2}{*}{ PD dummy } & $6.893^{* * *}$ & $4.211^{* * *}$ & & \\
\hline & $(0.817)$ & $(0.198)$ & & \\
\hline \multirow[t]{2}{*}{ TE dummy } & $7.051^{* * *}$ & $5.497^{* * *}$ & $2.242^{* * *}$ & $2.846^{* * *}$ \\
\hline & $(0.384)$ & $(0.214)$ & $(0.313)$ & $(0.122)$ \\
\hline \multicolumn{5}{|l|}{ Control variables } \\
\hline \multirow[t]{2}{*}{ Ln(Firm size) } & $1.110^{* * *}$ & $1.440^{* * *}$ & $-0.911^{* * *}$ & $-0.809 * * *$ \\
\hline & $(0.158)$ & $(0.095)$ & $(0.098)$ & $(0.054)$ \\
\hline \multirow[t]{2}{*}{ Ln(Firm age) } & & & $-2.035^{* * *}$ & $-3.216^{* * *}$ \\
\hline & & & $(0.373)$ & (0.137) \\
\hline \multirow[t]{2}{*}{ Ln(R\&D expense) } & -0.022 & $-0.246^{* *}$ & $-0.531^{* * *}$ & $-0.752^{* * *}$ \\
\hline & $(0.228)$ & $(0.087)$ & $(0.124)$ & $(0.054)$ \\
\hline \multirow{2}{*}{$\begin{array}{l}\text { Number of independent } \\
\text { directors }\end{array}$} & $0.578^{* *}$ & $0.176^{+}$ & $-0.559 * * *$ & $0.341^{* * *}$ \\
\hline & $(0.187)$ & $(0.104)$ & $(0.100)$ & $(0.055)$ \\
\hline \multirow{2}{*}{$\begin{array}{l}\text { CEO with international } \\
\text { education }\end{array}$} & 0.491 & $-1.210^{*}$ & 0.561 & $-1.235^{* * *}$ \\
\hline & $(0.711)$ & $(0.563)$ & $(0.381)$ & $(0.241)$ \\
\hline \multirow[t]{2}{*}{ Constant } & -1.992 & $1.760^{* *}$ & $10.909^{* * *}$ & $9.542^{* * *}$ \\
\hline & $(1.723)$ & $(0.555)$ & $(1.115)$ & $(0.329)$ \\
\hline \multirow[t]{2}{*}{ Fixed Effects } & Industry, & Industry & Industry, & Industry \\
\hline & Patent office & & Patent office & \\
\hline $\mathrm{N}$ & 247 & 2,026 & 238 & 1,224 \\
\hline R-square & 0.751 & 0.346 & 0.828 & 0.729 \\
\hline Adj. R-square & 0.736 & 0.342 & 0.817 & 0.726 \\
\hline
\end{tabular}

This table presents cross-sectional regression results using patent level data. $P D$ dummy is a dummy variable that is equal to one if the patent belongs to a Purely Domestic SME, and zero otherwise. TE dummy is a dummy variable that is equal to one if the patent belongs to a traditional exporter, and zero otherwise. Standard errors are in parentheses. ${ }^{+} p<0.1,{ }^{*} p<0.05,{ }^{* *} p<0.01,{ }^{* * *} p<0.001$ 
Table 4: Multivariate analysis of the number of patents filed and citations per patent.

\begin{tabular}{|c|c|c|c|c|}
\hline Variables & Model 3a & Model 3b & Model 4a & Model 4b \\
\hline Dependent variable: & $\begin{array}{l}\text { Number of foreign } \\
\text { patents filed }\end{array}$ & $\begin{array}{l}\text { Number of Chinese } \\
\text { patents filed }\end{array}$ & $\begin{array}{l}\text { Citations per } \\
\text { foreign patent }\end{array}$ & $\begin{array}{l}\text { Citations per } \\
\text { Chinese patent }\end{array}$ \\
\hline \multicolumn{5}{|l|}{ Independent variables } \\
\hline \multirow[t]{2}{*}{ PD dummy } & $-0.702^{* * *}$ & -0.133 & $9.537^{+}$ & 0.076 \\
\hline & $(0.128)$ & $(0.447)$ & (5.239) & $(0.133)$ \\
\hline \multirow[t]{2}{*}{ TE dummy } & 0.086 & $1.008^{*}$ & 5.089 & $0.575^{* * *}$ \\
\hline & $(0.145)$ & $(0.491)$ & $(3.225)$ & $(0.134)$ \\
\hline \multicolumn{5}{|l|}{ Control variables } \\
\hline \multirow[t]{2}{*}{ Ln(Firm size $)$} & 0.010 & $0.405^{*}$ & -0.209 & $-0.180^{* *}$ \\
\hline & $(0.052)$ & $(0.175)$ & $(0.099)$ & $(0.056)$ \\
\hline \multirow[t]{2}{*}{ Ln(Firm age) } & $-0.252^{+}$ & -0.538 & -2.558 & $-0.647^{* * *}$ \\
\hline & $(0.130)$ & (0.439) & $(4.067)$ & $(0.138)$ \\
\hline \multirow[t]{2}{*}{ Ln(R\&D expense) } & 0.018 & 0.209 & 0.104 & -0.042 \\
\hline & $(0.039)$ & $(0.132)$ & $(1.250)$ & $(0.047)$ \\
\hline \multirow[t]{2}{*}{ Ln(Patent age) } & & & $-5.086^{* * *}$ & $-0.251^{*}$ \\
\hline & & & (1.611) & $(0.097)$ \\
\hline \multirow{2}{*}{$\begin{array}{l}\text { Number of } \\
\text { independent directors }\end{array}$} & $0.396^{* * *}$ & 0.121 & 1.100 & $-0.160^{* *}$ \\
\hline & $(0.054)$ & $(0.184)$ & $(1.024)$ & $(0.055)$ \\
\hline \multirow{2}{*}{$\begin{array}{l}\text { CEO with international } \\
\text { education }\end{array}$} & $-0.488^{+}$ & $-1.708^{+}$ & $-6.781^{+}$ & $-0.593 *$ \\
\hline & $(0.262)$ & $(0.890)$ & (3.919) & $(0.297)$ \\
\hline \multirow[t]{2}{*}{ Have foreign patents } & & $1.838^{* * *}$ & & $0.252^{* *}$ \\
\hline & & $(0.401)$ & & $(0.092)$ \\
\hline \multirow[t]{2}{*}{ Constant } & -0.076 & 0.552 & 0.781 & $3.959 * * *$ \\
\hline & (0.319) & (1.081) & $(12.024)$ & $(0.443)$ \\
\hline Fixed Effects & Industry & Industry & $\begin{array}{l}\text { Industry, } \\
\text { Patent office }\end{array}$ & Industry \\
\hline $\mathrm{N}$ & 728 & 728 & 247 & 2,026 \\
\hline R-square & 0.145 & 0.101 & 0.157 & 0.083 \\
\hline Adj. R-square & 0.130 & 0.083 & 0.098 & 0.076 \\
\hline
\end{tabular}

This table presents regression results using firm-year panel-level data for Models 3a and $3 \mathrm{~b}$ and patent level data for Models 4a and 4b. PD dummy is a dummy variable that is equal to one if the firm is a Purely Domestic SME, and zero otherwise. TE dummy is a dummy variable that is equal to one if we classify it as a traditional exporter, and zero otherwise. Standard errors are in parentheses. ${ }^{+} p<0.1,{ }^{*} p<0.05,{ }^{* *} p<0.01,{ }^{* * *} p<0.001$ 
Table 5: Summary of key findings.

\begin{tabular}{llll}
\hline & Patent Filing & $\begin{array}{l}\text { Speed of } \\
\text { Internationalization }\end{array}$ & $\begin{array}{l}\text { Value of Innovation } \\
\text { over time (as } \\
\text { measured by patents } \\
\text { citations) }\end{array}$ \\
\hline $\begin{array}{l}\text { Chinese Born Globals } \\
- \text { YAGs }\end{array}$ & $\begin{array}{l}\text { Faster at filing } \\
\text { domestic and foreign } \\
\text { patents than other } \\
\text { firms. Uses patents } \\
\text { registration as signal of } \\
\text { intention to } \\
\text { internationalize. }\end{array}$ & $\begin{array}{l}\text { Rapid } \\
\text { internationalization } \\
\text { after receiving domestic } \\
\text { or foreign patents. }\end{array}$ & $\begin{array}{l}\text { Over time the number } \\
\text { of patent citations } \\
\text { does not increase } \\
\text { significantly, } \\
\text { suggesting these firms } \\
\text { do not remain } \\
\text { innovative. }\end{array}$ \\
$\begin{array}{llll}\text { Purely Domestic } \\
\text { SMEs-PDs }\end{array}$ & $\begin{array}{l}\text { Slower than YAGs to } \\
\text { file for patents. }\end{array}$ & Not applicable & $\begin{array}{l}\text { Domestic patent } \\
\text { citations increase over } \\
\text { time and PDs catch-up } \\
\text { to YAGs' citations of } \\
\text { patents. }\end{array}$ \\
& Slower than YAGs to & $\begin{array}{l}\text { Significantly longer } \\
\text { time to internationalize }\end{array}$ & $\begin{array}{l}\text { Citation of domestic } \\
\text { and foreign patents } \\
\text { increases over time } \\
\text { and TEs catch-up to }\end{array}$ \\
Exportitional & after receiving patents. & $\begin{array}{l}\text { YAGs citation of } \\
\text { patents }\end{array}$ \\
\hline
\end{tabular}


Appendix I. List of variables with definition and source

\begin{tabular}{|c|c|c|}
\hline Variable Name & Definition & Source \\
\hline \multicolumn{3}{|l|}{ Dependent variable } \\
\hline $\begin{array}{l}\text { Number of years from inception to } \\
\text { filing a foreign patent }\end{array}$ & $\begin{array}{l}\text { The number of years from when the firm is founded } \\
\text { until the foreign patent is filled }\end{array}$ & $\begin{array}{l}\text { Calculated from Thomson } \\
\text { Reuters and Google Patent data }\end{array}$ \\
\hline $\begin{array}{l}\text { Number of years from inception to } \\
\text { filing a Chinese patent }\end{array}$ & $\begin{array}{l}\text { The number of years from when the firm is founded } \\
\text { until the Chinese patent is filled }\end{array}$ & $\begin{array}{l}\text { Calculated from Thomson } \\
\text { Reuters and Google Patent data }\end{array}$ \\
\hline $\begin{array}{l}\text { Number of years between filing } \\
\text { foreign patent and internationalizing }\end{array}$ & $\begin{array}{l}\text { The number of years from when the foreign patent is } \\
\text { filled until the firm internationalize }\end{array}$ & $\begin{array}{l}\text { Calculated from Thomson } \\
\text { Reuters and Google Patent data }\end{array}$ \\
\hline $\begin{array}{l}\text { Number of years between filing } \\
\text { Chinese patent and internationalizing }\end{array}$ & $\begin{array}{l}\text { The number of years from when the Chinese patent is } \\
\text { filled until the firm internationalize }\end{array}$ & $\begin{array}{l}\text { Calculated from Thomson } \\
\text { Reuters and Google Patent data }\end{array}$ \\
\hline Number of foreign patents filed & The number of foreign patents a firm filed in a year & Google Patent \\
\hline Number of Chinese patents filed & The number of Chinese patents a firm filed in a year & Google Patent \\
\hline Citations per foreign patent & The number of citations of a foreign patent & Google Patent \\
\hline Citations per Chinese patent & The number of citations of a Chinese patent & Google Patent \\
\hline
\end{tabular}

\section{Variables of interest}

PD dummy

TE dummy

A dummy variable that is equal to one if the firm is a Purely Domestic SME, and zero otherwise

Thomson Reuters

A dummy variable that is equal to one if we classify it Thomson Reuters as a traditional exporter, and zero otherwise

\section{Control variables}

Firm size

Natural logarithm of total assets (in million USD)

Firm age

R\&D expense

Number of independent directors

CEO with international education

Patent age

Have foreign patents

Natural logarithm of firm age

Natural logarithm of R\&D expense

Proportion of independent directors

A dummy variable that is equal to one if the CEO of the firm has at least one year of international education, and zero otherwise

Natural logarithm of the patent age

A dummy variable that is equal to one if the firm has foreign patents, and zero otherwise
Thomson Reuters

Thomson Reuters

Thomson Reuters

Thomson Reuters

Thomson Reuters

Google Patent

Google Patent 
Appendix II. Multivariate analysis of industry-adjusted speed of patenting.

\begin{tabular}{|c|c|c|c|c|}
\hline Variables & Model 1a & Model 1b & Model 2a & Model 2b \\
\hline Dependent variable: & $\begin{array}{l}\text { \# years from inception } \\
\text { to filing a foreign patent } \\
\text { (industry adjusted) }\end{array}$ & $\begin{array}{l}\text { \# years from inception } \\
\text { to filing a Chinese } \\
\text { patent (industry } \\
\text { adjusted) }\end{array}$ & $\begin{array}{l}\text { \# years between filing } \\
\text { foreign patent and } \\
\text { internationalizing } \\
\text { (industry adjusted) }\end{array}$ & $\begin{array}{l}\text { \# years between filing } \\
\text { Chinese patent and } \\
\text { internationalizing } \\
\text { (industry adjusted) }\end{array}$ \\
\hline \multicolumn{5}{|l|}{ Independent variables } \\
\hline \multirow[t]{2}{*}{ PD dummy } & $5.085^{* * *}$ & $3.534^{* * *}$ & & \\
\hline & $(0.886)$ & $(0.199)$ & & \\
\hline \multirow[t]{2}{*}{ TE dummy } & $5.426^{* * *}$ & $4.459^{* * *}$ & 0.116 & $0.638^{* * *}$ \\
\hline & $(0.384)$ & $(0.203)$ & $(0.287)$ & $(0.130)$ \\
\hline \multicolumn{5}{|l|}{ Control variables } \\
\hline \multirow[t]{2}{*}{ Ln(Firm size $)$} & $0.748^{* * *}$ & $0.888^{* * *}$ & $-1.065^{* * *}$ & $-0.783^{* * *}$ \\
\hline & $(0.174)$ & $(0.093)$ & $(0.108)$ & $(0.070)$ \\
\hline \multirow[t]{2}{*}{ Ln(Firm age) } & & & -0.309 & $-1.363^{* * *}$ \\
\hline & & & $(0.404)$ & $(0.170)$ \\
\hline \multirow[t]{2}{*}{ Ln(R\&D expense) } & $0.963^{* * *}$ & 0.045 & $-0.308^{*}$ & $-0.594^{* * *}$ \\
\hline & $(0.237)$ & $(0.090)$ & $(0.134)$ & $(0.071)$ \\
\hline \multirow{2}{*}{$\begin{array}{l}\text { Number of independent } \\
\text { directors }\end{array}$} & $-0.448^{* * *}$ & -0.093 & $-1.146^{* * *}$ & $0.140^{+}$ \\
\hline & $(0.152)$ & $(0.108)$ & $(0.095)$ & $(0.073)$ \\
\hline \multirow{2}{*}{$\begin{array}{l}\text { CEO with international } \\
\text { education }\end{array}$} & -0.036 & -0.338 & -0.209 & $-2.637^{* * *}$ \\
\hline & $(0.828)$ & $(0.587)$ & $(0.459)$ & $(0.320)$ \\
\hline \multirow[t]{2}{*}{ Constant } & $-3.466^{*}$ & $-5.347^{* * *}$ & $8.989^{* * *}$ & $4.699^{* * *}$ \\
\hline & $(1.648)$ & $(0.505)$ & $(1.262)$ & $(0.387)$ \\
\hline Fixed Effects & Patent office & & Patent office & \\
\hline $\mathrm{N}$ & 247 & 2,026 & 238 & 1,224 \\
\hline R-square & 0.602 & 0.242 & 0.800 & 0.384 \\
\hline Adj. R-square & 0.585 & 0.240 & 0.792 & 0.381 \\
\hline
\end{tabular}

This table presents pooled regression results using patent level data. The industry adjustment is done by taking the variable of interest and subtracting it by the industry average. $P D$ dummy is a dummy variable that is equal to one if the patent belongs to a Purely Domestic SME, and zero otherwise. TE dummy is a dummy variable that is equal to one if the patent belongs to a traditional exporter, and zero otherwise. Standard errors are in parentheses. ${ }^{+} p<0.1,{ }^{*} p<0.05,{ }^{* *} p<0.01,{ }^{* * *} p<0.001$ 
Appendix III. Multivariate analysis of the number of patents filed and citations per patent (industry-adjusted).

\begin{tabular}{|c|c|c|c|c|}
\hline Variables & Model 3a & Model 3b & Model 4a & Model 4b \\
\hline Dependent variable: & $\begin{array}{l}\text { Number of foreign } \\
\text { patents filed } \\
\text { (industry adjusted) }\end{array}$ & $\begin{array}{l}\text { Number of Chinese } \\
\text { patents filed } \\
\text { (industry adjusted) }\end{array}$ & $\begin{array}{l}\text { Citations per } \\
\text { foreign patent } \\
\text { (industry adjusted) }\end{array}$ & $\begin{array}{l}\text { Citations per } \\
\text { Chinese patent } \\
\text { (industry adjusted) }\end{array}$ \\
\hline \multicolumn{5}{|l|}{ Independent variables } \\
\hline \multirow[t]{2}{*}{ PD dummy } & $-0.638^{* * *}$ & -0.117 & 4.383 & -0.018 \\
\hline & $(0.120)$ & $(0.423)$ & $(4.724)$ & $(0.127)$ \\
\hline \multirow[t]{2}{*}{ TE dummy } & 0.124 & $0.993^{*}$ & 1.118 & $0.381^{* *}$ \\
\hline & $(0.140)$ & $(0.474)$ & $(2.502)$ & $(0.121)$ \\
\hline \multicolumn{5}{|l|}{ Control variables } \\
\hline \multirow[t]{2}{*}{ Ln(Firm size) } & -0.008 & $0.421^{*}$ & -0.848 & -0.059 \\
\hline & $(0.051)$ & $(0.172)$ & $(0.894)$ & $(0.053)$ \\
\hline \multirow[t]{2}{*}{ Ln(Firm age) } & $-0.247^{+}$ & -0.604 & 0.358 & $-0.448^{* *}$ \\
\hline & $(0.128)$ & $(0.434)$ & $(3.676)$ & $(0.136)$ \\
\hline \multirow[t]{2}{*}{ Ln(R\&D expense) } & 0.030 & $0.218^{+}$ & 1.314 & $-0.091 *$ \\
\hline & $(0.037)$ & $(0.125)$ & (1.119) & $(0.046)$ \\
\hline \multirow[t]{2}{*}{ Ln(Patent age) } & & & $-5.181^{* *}$ & $-0.191 *$ \\
\hline & & & $(1.565)$ & (0.099) \\
\hline \multirow{2}{*}{$\begin{array}{l}\text { Number of } \\
\text { independent directors }\end{array}$} & $0.390^{* * *}$ & 0.167 & -0.175 & $-0.158^{* *}$ \\
\hline & $(0.053)$ & $(0.092)$ & $(-0.22)$ & $(0.055)$ \\
\hline \multirow{2}{*}{$\begin{array}{l}\text { CEO with international } \\
\text { education }\end{array}$} & -0.416 & $-2.002^{*}$ & $-8.483^{*}$ & $-0.816^{* *}$ \\
\hline & $(0.254)$ & $(0.864)$ & $(3.816)$ & (0.299) \\
\hline \multirow[t]{2}{*}{ Have foreign patents } & & $1.713^{* * *}$ & & $0.314^{* *}$ \\
\hline & & $(0.393)$ & & $(0.094)$ \\
\hline \multirow[t]{2}{*}{ Constant } & -0.005 & 0.017 & 7.107 & $1.195^{* *}$ \\
\hline & $(0.297)$ & $(1.006)$ & (11.395) & $(0.423)$ \\
\hline Fixed Effects & & & Patent office & \\
\hline $\mathrm{N}$ & 728 & 728 & 247 & 2,026 \\
\hline R-square & 0.130 & 0.082 & 0.140 & 0.043 \\
\hline Adj. R-square & 0.122 & 0.072 & 0.095 & 0.038 \\
\hline
\end{tabular}

This table presents regression results using firm-year panel-level data for Models $3 \mathrm{a}$ and $3 \mathrm{~b}$ and patent level data for Models $4 \mathrm{a}$ and $4 \mathrm{~b}$. The industry adjustment is done by taking the variable of interest and subtracting it by the industry average. $P D$ dummy is a dummy variable that is equal to one if the firm is a Purely Domestic SME, and zero otherwise. TE dummy is a dummy variable that is equal to one if we classify it as a traditional exporter, and zero otherwise. Standard errors are in parentheses. ${ }^{+} p<0.1,{ }^{*} p<0.05,{ }^{* *} p<0.01,{ }^{* * *} p<0.001$ 